\title{
A case of acute measles meningoencephalitis with virus isolation
}

\author{
D. R. PURDHAM AND P. F. BATTY \\ From the Virology Laboratory, Children's Hospital, Ladywood, Birmingham, and Worcester Royal Infirmary
}

SYNOPSIS A case of measles meningoencephalitis is described. Measles virus was isolated from the ${ }^{\omega}$ cerebrospinal fluid cells, in which virus antigen was also detected by indirect immunofluorescence. $\bar{\nabla}$

Measles virus is difficult to isolate from infections of the central nervous system. Only by cocultivation techniques is it possible to isolate the virus from brain material in cases of subacute sclerosing panencephalitis (Horta-Barbosa, Fucillo, Sever, and Zeman, 1969; Purdham, 1974), and it has been suggested that this is also the case in primary measles encephalitis (ter Meulen, Käckell, Müller, Katz, and Meyermann, 1972). Transmission of infection to monkeys using brain material (Scott, 1967), and a single report of successful virus isolation from cerebrospinal fluid taken from a patient with measles encephalitis (McLean, Best, Smith, Larke, and McNaughton, 1966) are among the scanty reports on the recovery of virus from acute measles encephalitis.

\section{Case Report}

A 6-year-old English boy became ill with a characteristic morbilliform rash, fever, and anorexia. Four days later he was admitted to hospital with generalized convulsions which were controlled with intravenous diazepam. On admission his temperature was $40^{\circ} \mathrm{C}$ and pulse $160 /$ minute. He had a fading generalized rash and appeared emaciated and slightly dehydrated. The total blood leucocyte count was $23000 / \mathrm{cmm}$, of which $80 \%$ were neutrophils; serum electrolytes were normal; blood urea was $9.8 \mathrm{mmol} /$ litre. He was treated with intravenous maintenance fluids throughout, and also initially with ampicillin and sulphadiazine.

He showed some improvement nine days after the onset of the rash, in both consciousness and speech, but still remained confused and disorientated. Lumbar CSF taken on the eleventh day contained 190 nucleated cells $/ \mathrm{cmm}$, of which $85 \%$ were lymphocytes; CSF sugar was $5.7 \mathrm{mmol} / \mathrm{litre}$, and protein was $0.42 \mathrm{~g} /$ litre. When the diagnosis of

Received for publication 4 September 1974. measles encephalitis was determined from this $\vec{N}$ specimen, ACTH therapy was started. However, $14 \varnothing$ days after the onset of the rash, he deteriorated with increasing tone, dilating pupils, unconsciousness, $\stackrel{\supset}{\vec{D}}$ and vomiting; he died the following day. Permission $\vec{\square}$ for necropsy was not given.

\section{Virological Studies}

\section{IMMUNOFLUORESCENCE}

The lumbar CSF was lightly centrifuged and tof cellular deposit washed in phosphate-buffered saline (PBS), pH 7.2, three times, from which drop prepara tions were made on standard microscope slidès. These were air-dried and fixed in acetone at $-20^{\circ} \mathrm{C}_{0}^{\circ}$

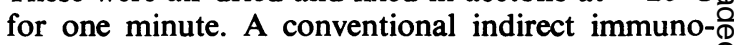
fluorescence method was used employing rabbit antimeasles serum, and a conjugated goat antirabbitglobulin serum. In one control preparation the specific antimeasles serum was replaced by pre-? immune rabbit serum, on a second preparation by rabbit antiherpesvirus hominis serum, and a third중 control preparation was treated with no serum, ie, $;-$ fluorescent conjugate only; the control smears were 3 . identical to those of the test and were treated in parallel with them.

\section{SEROLOGY}

The patient's serum was tested for the presence of antibodies to measles virus by complement-fixation (CF), and his CSF by complement-fixation and haemagglutination-inhibition (HAI) tests.

\section{ISOLATION}

The PBS-washed cells from the CSF were inoculated into primary rhesus monkey kidney cell monolayers which were incubated stationary at $35^{\circ} \mathrm{C}$. The tissues cultures were examined for cytopathic effects thrice weekly, and tested at five-day intervals for haem-o adsorption using $0.5 \%$ rhesus monkey erythrocytes 
in PBS at $37^{\circ} \mathrm{C}$. Typing was carried out by neutralization, haemadsorption-inhibition, and indirect immunofluorescence, with specific antisera.

\section{Results}

IMMUNOFLUORESCENCE

Bright fluorescence was seen in a number of CSF cells in both the cytoplasm and the nucleus, and was generally granular in appearance. A few of the cells also exhibited fluorescing intranuclear areas (fig), which by phase-contrast microscopy resembled inclusion bodies. Only very faint non-specific staining was visible in the control cells.

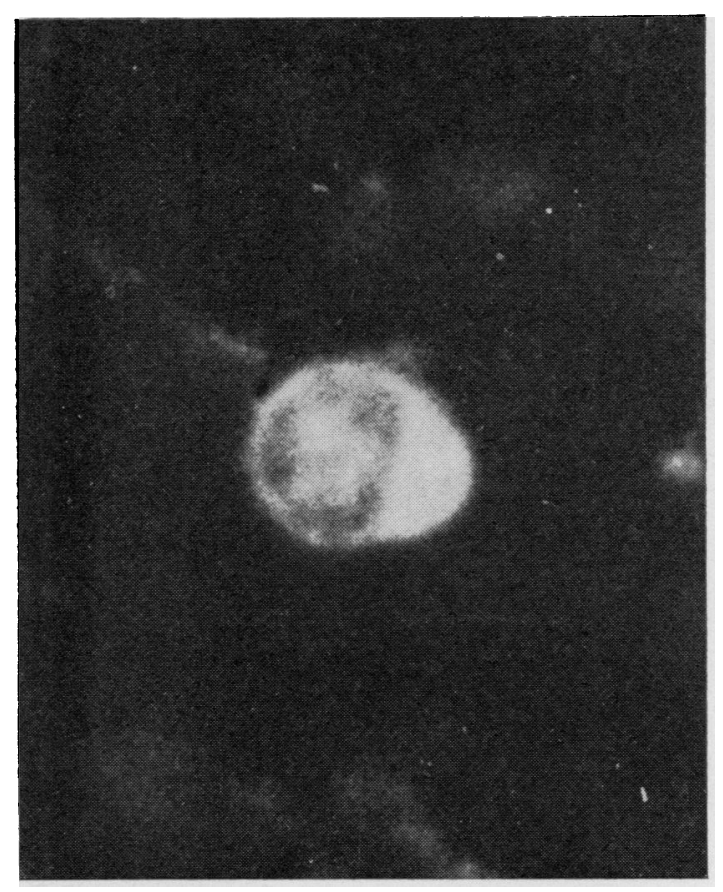

Fig Cerebrospinal fuid cell containing fuorescing measles antigen in both cytoplasm and nucleus.

\section{SEROLOGY}

The only serum sample available for virus studies was collected 10 days after the appearance of the rash and had a CF antibody titre to measles virus of $1: 256$. The supernatant fluid of the CSF taken on the eleventh day was negative for measles antibody by both CF and HAI tests.

\section{ISOLATION}

After 10 days' incubation, foci of infection in the form of multinucleated giant cells and cellular degenerative areas were visible in the tissue cultures, all of which were positive by haemadsorption. On subculture these effects were transmissible to further monkey kidney cultures but not to HeLa or HEp 2 cells. Immunofluorescence tests revealed measles antigen in the inoculated cultures, and the isolate was typed by both virus neutralization and haemadsorption-inhibition tests.

\section{Discussion}

The isolation of measles virus from the central nervous system in cases of acute encephalitis may be as difficult as in cases of subacute sclerosing panencephalitis (ter Meulen et al, 1972). However, virus in a 'defective' form was not a problem in this case, as the agent was freely recoverable by standard tissue culture methods, although it might be argued that in fact cocultivation of washed CSF cells and rhesus monkey kidney cells was done. The use by others of immunofluorescence for demonstrating virus antigen in CSF cells (Somervilie, 1966; Dayan and Stokes, 1973) has encouraged us to apply this rapid technique at every opportunity, but like others (Tomlinson and MacCallum, 1973), unsuccessfully (until now). The antiserum specificity, control methods employed, morphology of reacting cells, and the fact that measles virus was isolated validate the immunofluorescence result. Contributory factors in this case to successful isolation and immunofluorescence may include: (1) plenty of nucleated cells in the CSF and (2) absence of measles antibody in the CSF, which, even if present at undetectable levels, could have been removed mechanically when the cells were washed. Detection of measles virus replication in tissue culture is greatly facilitated by regular haemadsorption tests with monkey erythrocytes; this will often detect virus even in the absence of cytopathic effects, which may not become evident until further passage. The fact that the results of Somerville and Dayan have not been confirmed, apart from our present single success, suggests that the presence of viral antigen detectable by immunofluorescence in the cells of lumbar CSF is not a common occurrence.

We thank Dr T. H. Flewett for his valuable advice in preparing this paper.

\section{References}

Dayan, A. D., and Stokes, M. I. (1973). Rapid diagnosis of encephalitis by immunofluorescent examination of cerebrospinal fluid cells. Lancet, 1, 177-179.

Horta-Barbosa, L., Fucillo, D. A., Sever, J. L., and Zeman, W. (1969). Subacute sclerosing panencephalitis; isolation of measles virus from a brain biopsy. Nature (Lond.), 221, 974. 
McLean, D. M., Best, J. M., Smith, P. A., Larke, R. P. B., and McNaughton, G. A. (1966). Viral infections of Toronto children during 1965: II. Measles encephalitis and other complications. Canad. med. Ass. J., 94, 905-910.

Purdham, D. R. (1974). Diagnosis of subacute sclerosing panencephalitis by serial tissue co-cultivation. J. med. Microbiol., 7, 299-300.

Scott, T. F. M. (1967). Postinfectious and vaccinal encephalitis. Med. clin. N. Amer., 51, 701-717.
Somerville, R. G. (1966). Rapid identification of neurotropic viruses by an immunofluorescent technique applied to cerebrospinal fluid cellular deposits. Arch. Virusforsch., 19, 63-69.

ter Meulen, V., Käckell, Y., Müller, D., Katz, M., and Meyermann, R. (1972). Isolation of infectious measles virus in measles ence- $\stackrel{\mathscr{D}}{\oplus}$ phalitis. Lancet, 2, 1172-1175.

Tomlinson, A. H., and MacCullam, F. O. (1973). Virus antigen in cells of lumbar cerebrospinal fluid (Letter). Lancet, 1, 319-320.

\section{The November 1974 Issue}

\section{THE NOVEMBER 1974 ISSUE CONTAINS THE FOLLOWING PAPERS}

Immunological studies in a case of T-cell leukaemia G. STATHOPOUlOS, M. PAPAMIChaIL, P. SHELdON, D. CATOVSKY, A. J. S. DAVIES, E. J. HOLBOROW, AND EVE WILTSHAW

High counting rates from ${ }^{125}$ I in radioimmunoassays T. K. BELL

The role of circulating hepatitis B antigen/antibody immune complexes in the pathogenesis of vascular and hepatic manifestations in polyarteritis nodosa CHRISTIAN G. TREPO, ARIE J. ZUCKERMAN, RICHARD C. BIRD, AND ALFRED M. PRINCE

Capillary blood collection in haematology $\mathrm{J}$. STUART, B. A. BARRETT, AND D. R. PRANGNELL

Folates in human serum K. RATANASTHIEN, J. A. BLAIR, R. J. LEEMING, W. T. COOKE, AND V. MELIKIAN

A simple method for the clinical determination of the mitotic activity of the human prostate in vitro K. E. O. SENIUS, J. PIETILÄ, I. ARVOLA, AND P. TUOHIMAA

Culture of specimens other than sputum for Mycobacteria D. A. MITCHISON AND V. R. ABER

Unusual skin sepsis due to a strain of multiresistant Staphylococcus aureus JOY HARRISON AND R. W. LACEY

Comparison of the titres of ASO, anti-DNase B, and antibodies against the group polysaccharide of group A streptococci in children with streptococcal infections L. E. GOEDVOLK-DE GROOT, N. MICHELBENSINK, M. M. VAN ES-BOON, A. H. VAN VONNO, AND M. F. MICHEL
Sensitivity of Streptococcus pyogenes to sulphamethoxazole, trimethoprim, and cotrimoxazole E. $\vec{N}$ YOURASSOWSKY, M. P. VANDERLINDEN, AND E. $\&$ SCHOUTENS

The rapid recognition of Lancefield group B haemolytic streptococci R. J. FALLON

Bactericidal capacity of peripheral blood leucocytes in relation to bacterial infections in acute lymphoblastic leukaemia in childhood EILEEN N. THOMPSO AND RALPH WILLIAMS

Indirect immunofluorescence test for the detection of Aspergillus fumigatus antibodies D. W. WARNOCK

Separation of three isoenzymes of $\mathrm{N}$-acetyl- $\beta$-Dhexosaminidase from human tissues by cellulose acetate membrane electrophoresis A. WESTWOOD AND D. N. RAINE

Plasma alkaline phosphatase isoenzymes in hepatobiliary disease A. O. AFONJA AND D. N. BARON

Sterilization of the biological safety cabinet S. W. B. NEWSOM AND B. M. WALSINGHAM

\section{Technical method}

A simple and rapid method for the differentiation of the members of the genus Klebsiella R. FREEMAN

Book review

Notice

The Association of Clinical Pathologists: 93rd general meeting

Copies are still available and may be obtained from the PUBLISHING MANAGER, BRITISH MEDICAL ASSOCIATION, TAVISTOCK SQUARE, LONDON, WClH 9JR, price $£ 1.05$. 